УДК 811.111’276.5:61

DOI:

Лариса Дудікова, кандидат педагогічних наук, доиент завідувач кафедри іноземних мов з курсом латинської мови та медичної термінологї Вінницького національного медичного університету імені М.I. Пирогова

Аліна Марлова, кандидат педагогічних наук, доцент кафедри іноземних мов з курсом латинської мови та медичної термінологї Вінницького національного медичного університету імені М.I. Пирогова

\title{
ОСОБЛИВОСТІ АНГЛІЙСЬКОГО МЕДИЧНОГО СЛЕНГУ ТА ОЗНАЙОМЛЕННЯ З НИМ СТУДЕНТІВ ВИЩИХ МЕДИЧНИХ НАВЧАЛЬНИХ ЗАКЛАДІВ ЯК ЗАСІБ МОТИВУВАННЯ ДО ВИВЧЕННЯ ІНОЗЕМНОЇ МОВИ
}

У статті представлено структурні та семантичні особливості англійського медичного сленгу та теми, яких він торкається. Визначено структурні засоби утворення сленгових слів і виразів (скорочення, словоскладання та утворення акронімів) та їх семантичні трансформації (метафоризація та метонімія). 3 'ясовано, щз найбільш поширеними способами утворення сленгових одиниць є акронімія, часто з набуттям переносного значення, та метафора. Проаналізовано характерні приклади англійського медичного сленгу. Авторами запропоновано приклади завдань для ознайомлення студентів з особливостями нестандартноі професійної лексики.

Ключові слова: англійський медичний сленг; мотивація; скорочення слова; словоскладання; абревіатура; акронім; метафора; метонімія.

Табл. 2. Літ. 12.

Larysa Dudikova, Ph.D.(Pedagogy), Associate Professor, Head of the Foreign Languages Department including Latin and Medical Terminology

Vinnytsya Mykola Pyrohov National Medical University Alina Marlova, Ph.D. (Pedagogy), Associate Professor of the Foreign Languages Department including Latin and Medical Terminology Vinnytsya Mykola Pyrohov National Medical University

\section{PECULIARITIES OF ENGLISH MEDICAL SLANG AND INTRODUCTION IT TO STUDENTS OF HIGHER MEDICAL EDUCATIONAL INSTITUTIONS AS MEANS OF MOTIVATING THEM FOR FOREIGN LANGUAGE LEARNING}

The article presents characteristic properties of slang words and expressions used in nonofficial communication of health professionals in English-speaking countries recently. It defines structural and semantic peculiarities of English medical slang and subjects it concerns. Analysis of scientific literature and non-standard medical lexical units demonstrated that slang words and expressions were formed by means of structural changes such as word reduction, compounding, abbreviations, or acronyms, and semantic transformations such as metaphorization and metonymy. The most common mechanism of structural formation of English medical slang units was found to be abbreviations, or acronyms, often with figurative meaning. The possible difference between abbreviations and acronyms was defined and illustrated. Different kinds of word reduction and compounding were determined and demostrated. Semantic ways of formation of nonofficial words and expressions were shown to be metaphorization and metonimia and metaphor when the object was attributed alien signs was more common. To make speech more expressive facetious expressions were often used. Sometimes new words incomprehensible to wide audience were formed from two unselectional in denotation parts, the first one being a part of an English word and the second one - a Greco-Latin terminoelement.

English medical slang concerns different subjects including medical drugs; therapeutic notions; health care professionals and their characteristics; patients and their conditions; medical procedures; medical institutions and their units. Lexical items denoting medical drugs were formed by word reduction, compounding, abbreviations, sometimes with metaphor. Slang units denominating therapeutic notions were constituted by all abovementioned means. The dominant mechanism of formation of nonofficial lexical items denoting people was metaphor, sometimes with structural changes, and slang words and expressions referring to patients and their conditions often having offensive meaning. Non-standard words to define medical procedures were foremost constituted by word reduction. In formation of slang items denominating medical institutions and their units, metaphor sometimes with word reduction or compounding was used. To introduce professional slang words and expressions to students for examples of tasks built on matching slang units with their definitions are suggested. 


\section{ОСОБЛИВОСТІ АНГЛЙСЬКОГО МЕДИЧНОГО СЛЕНГУ ТАОЗНАЙОМЛЕННЯ ЗНИМ СТУДЕНТІВ ВИЩИХ МЕДИЧНИХ НАВЧАЛЬНИХЗАКЛАДІВ ЯК ЗАСІБ МОТИВУВАННЯ ДО ВИВЧЕННЯ IНОЗЕМНОЇМОВИ}

In conclusion the authors assert that introduction of English medical slang to students enriches their professional vocabulary by lexical items relevant in modern nonofficial communication of medical professions of English-speaking countries and thus motivates them for language learning.

Keywords: English medical slang; motivation; word reduction; compounding; abbreviation; acronym; metaphor; metonimia.

П остановка проблеми. Останнім часом в розмовну мову швидкими темпами проникає сленг, який поступово переходить у стандартне мовлення. Прослідковується широке використання сленгу в професійних колах, де він має свою специфікуі не завжди зрозумілий для широкого кола. Яскравим прикладом широкого розповсюдження нестандартних слів і виразів, що стосуються певної професійної діяльності, є медичний сленг.

Медичний сленг - це форма сленгу, що використовується лікарями, медсестрами та іншим лікарським або медичним персоналом. Його сутність полягає у використанні жартівливих, але іноді провокативних при озвученні акронімів і вигаданих термінів для описання пацієнтів, колег або неспецифічних ситуацій. Іншими словами, медичний сленг виступає як зручний, але деколи цинічний мовленнєвий код між лікарями та іншим персоналом лікарень. Метою вживання медичного сленгу $є$ економія часу i зусиль, виразність і дотепність мови, демонстрація власної обізнаності в професійній галузі, кодування інформації від сторонніх осіб. Медичний сленг існує в багатьох мовах, але в англомовних країнах він увійшов у загальну культуру завдяки телевізійним серіалам про лікарів і судовомедичних експертів.

Основною причиною використання нестандартних одиниць, на думку основоположника наукового підходу до вивчення англійського медичного сленгу А. Фокса, є психологічні чинники. На думку науковця, медичний сленг підтримує дистанцію між лікарем і пацієнтом та допомагає полегшувати напруження властиве даній професії. Сленг створює умови для духу колективізму, відчуття взаємної підтримки і загальної мети [2, 176 - 177].

Ознайомлення студентів вищих медичних навчальних закладів з англійськими нестандартними словами і виразами з їх професійної галузі під час курсу іноземної мови урізноманітнює навчальний процес і збагачує іншомовний професійний словниковий запас майбутніх лікарів. Знання англійських медичних сленгізмів надає їм можливість відчути себе частиною інтернаціональної професійної спільноти, що сприяє зростанню мотивації до вивчення іноземної мови.

Аналіз останніх досліджень і публікацій. Оскільки медичний сленг має не таку давню історію та йому притаманна смислова словотворча динаміка, у науковій літературі представлена невелика кількість наробок у цій площині.

Перший список сленгових одиниць, поширених у лікарнях Великобританії, був укладений лікаремалергологом А. Фоксом. Науковець обгрунтував виникнення даного феномену, дослідив сфери застосування і походження медичних сленгових виразів, а також етичні та правові аспекти використання нестандартної термінології [2].

В подальшому дослідження сленгу в клінічній практиці проводилось П. Макдональдом, доцентом університету Великобританії, який доповнив список медичних сленгізмів А. Фокса сучасними нестандартними лексичними одиницями, відібраними з медичної літератури [8].

Лікар-консультант П. Кілі вивчав медичні неологізми, які з'явилися в останні роки завдяки інтенсивному розповсюдженню електронних ресурсів [6].

Сприйняття студентами-медиками гумору i сленгу в стаціонарних умовах Сполучених Штатів, а саме, як вони вони реагують на нестандартні висловлювання медичних працівників і колегстудентів та як вони до них ставляться, розглядалось Ж. Нун Парсонс, С. Б. Кінсман, Ч. Л. Боском та ін. [10]

Відмінності медичного сленгу і жаргону та навчання їх майбутніх працівників охорони здоров’я у Венгрії досліджувала М. Гіуро [4].

Професійний сленг, жаргон і прислів'я вивчалися Я. Стояновою у площині неформального медичного дискурсу [11].

Окремі характеристики медичного сленгу в англомовних країнах, головним чином його психологічний та етичний аспекти, висвітлювалися в періодичних виданнях $[3 ; 5 ; 7 ; 12]$.

Метою статті $\epsilon$ дослідження особливостей англійського медичного сленгу, його тематики та способів утворення і шляхів ознайомлення $з$ ним майбутніх лікарів з метою мотивування їх до вивчення іноземної мови.

Виклад основного матеріалу. Навчання сленгу під час занять англійської мови $є$ досить суперечливим питанням та іноді викликає сумніви у викладачів, однак, зростаюча кількість нестандартної лексики в галузі медицини демонструє, що ця спеціальна термінологія складає невід'ємну частину мови [4, 41 - 42] i потребує ознайомлення 3 нею майбутніх лікарів 


\section{ОСОБЛИВОСТІ АНГЛЙСЬКОГО МЕДИЧНОГО СЛЕНГУ ТАОЗНАЙОМЛЕННЯ З НИМ СТУДЕНТІВ ВИЩИХ МЕДИЧНИХ НАВЧАЛЬНИХ ЗАКЛАДІВ ЯК ЗАСІБ МОТИВУВАННЯ ДО ВИВЧЕННЯ IНОЗЕМНОЇМОВИ}

для вільного спілкування з носіями мови в неофіційному медичному дискурсі.

Аналіз наукової літератури $[2 ; 4 ; 11]$ та медичних неофіційних слів і виразів засвідчив, що сленгові одиниці утворюються за допомогою тих самих засобів, як і в стандартній мові, а саме: скорочення слова, словоскладання та утворення акронімів, або абревіатур. Щодо семантичного аспекту, то слова і вирази здебільшого набувають переносного значення завдяки метафоризації (вживанню слів і виразів у переносному значенні на основі аналогії, схожості, порівняння) та метонімії (використанню звороту мови або слова, яким замінюється суміжне поняття).

Найбільш розповсюдженим засобом утворення англійських медичних сленгізмів $є$ абревіатури. Такий метод розвитку медичного сленгу є досить продуктивним, оскільки максимальне скорочення слів і висловів заощаджує час медичного персоналу та сприяє швидкому розумінню та засвоєнню інформації. Як правило, абревіатури вимовляються по окремих літерах:

$B B A$ - "born before arrival" - народжений до прибуття в лікарню;

$C T$ - “computerized tomography" - комп’ютерна томографія;

$D N A$ - "deoxyribonucleic acid" дезоксирибонуклеїнова кислота;

$O D$ - "overdose" - надмірна доза.

Близькими за значенням до абревіатур є акроніми. Іноді ці два терміни ототожнюють; іноді їх відмінність вбачають у тому, що акроніми асимілюються мовою і стають самостійними словами, що вимовляються відповідно до правил читання як одне слово.

Простий приклад акронімії - AIDS (СНIД), "acquired immune deficiency syndrome" (синдром набутого імунодефіциту). Цей термін увійшов в англійську мову у 80-х роках і швидко став повноправним словом, хоча назва ретровірусу, який викликає цю хворобу - HIV (ВIЛ), "human immunodeficiency virus" (вірус імунодефіциту людини), залишилась у статусі абревіатури та вимовляється як три окремі літери.

Подекуди поряд 3 прямим значенням при неофіційному спілкуванні медичного персоналу акроніми, або абревіатури, набувають переносного значення:

$M I$ - "myocardial infarction, or monetary insufficiency" - інфаркт міокарда або грошова недостатність;

$N A D$ - "no abnormality detected, or to the junior doctor: not actually done" - ніякої аномалії не виявлено або до лікаря-стажера: насправді нічого не зроблено;
$W N L$ - "within normal limits, or we didn't look" в межах норми або ми не дивилися.

Окрім загально-прийнятих абревіатур i акронімів медичних термінів, виникли абревітури і акроніми розмовних виразів, грубих і образливих або просто дотепних:

$F L K$ - "funny looking kid" - дитина, що дивно виглядає (іноді для визначення синдрому Дауна або зовнішніх ознак розумової відсталості);

GOK - "God only knows" - Бог його знає (визнання відсутності інформації);

TEETH - "tried everything else, try homeopathy" - спробували все, спробуйте гомеопатію (визнання безсилля медичних засобів).

Наступним продуктивним способом утворення сленгових одиниць $є$ скорочення слів, або утворення нових форм слова за допомогою скорочення вже існуючих. С чотири типи скорочень: скорочення, в якому зберігається перша частина слова; скорочення, при якому вилучаються перші літери; скорочення, коли вилучається середина слова; скорочення, коли вилучаються частини обох слів у словосполученні:

chem - "chemical analysis" - хімічний аналіз;

$l a b$ - "laboratory" - лабораторія;

lytes - "electrolytes" - електроліти;

post op - "post operative condition" післяопераційний стан пацієнта;

tern - "intern" - інтерн.

Однак, найбільш продуктивним джерелом утворення медичного сленгу виступає метафора, коли об'єкту приписуються чужі властивості та ознаки. Для увиразнення мови часто вживаються жартівливі, глузливо-іронічні, іноді зневажливі вирази:

blue pipe (блакитна трубка) - вена;

box (опинитися у ящику) - померти;

red pipe (червона трубка) - артерія;

ward $X$ (палата Икс) - морг.

Деколи із звичних словотворчих елементів утворюються нові слова, незрозумілі широкому колу. Наприклад, сленгізм fascinoma побудований на основі англійського слова fascinating (дуже цікавий) та латинського терміноелементу -ота (пухлина) і означає "дуже цікаве захворювання". Іншим прикладом $\epsilon$ лексичне утворення hospitalitis, яке складається 3 англійського слова hospital (лікарня) та латинського терміноелементу -itis (запалення), та означає “хвороба, яка розвивається після довгого перебування в лікарні". Сленгізм noctor (медсестра-лікар) утворений з початкової літери слова nurse (медсестра) та слова doctor без першої літери (лікар) і означає медсестру, яка 


\section{ОСОБЛИВОСТІ АНГЛЙСЬКОГО МЕДИЧНОГО СЛЕНГУ ТАОЗНАЙОМЛЕННЯ З НИМ СТУДЕНТІВ ВИЩИХ МЕДИЧНИХ НАВЧАЛЬНИХ ЗАКЛАДІВ ЯК ЗАСІБ МОТИВУ ВАННЯ ДО ВИВЧЕННЯ IНОЗЕМНОЇМОВИ}

відвідувала курси інтенсивної підготовки та виконує обов'язки лікаря у відділенні.

Сленгові одиниці мають різноманітну тематику та вживаються у всіх сферах медичної галузі, означаючи медичні препарати та показники, кваліфікації медичного персоналу та стан хворих, медичні процедури та підрозділи.

Сленгізми, що мають фармакологіче значення, утворюються переважно за допомогою скорочень, словоскладання, утворення абревіатур, рідше метафори або метонімії:

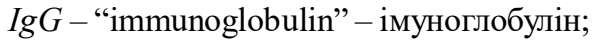

pills - "painkillers" - болезаспокійливі;

meth - "methamphetamine" - метамфітамін;

vitamin $H$ - "haloperidol" - галоперідол.

Сленгові утворення, що належать до терапевтичної групи, утворюються за допомогою всіх засобів словотворення:

$B P$ - "blood pressure" - кров'яний тиск;

fits (конвульсії) - раптовий напад судом;

vitals - "pulse, blood pressure and other vital indices" - пульс, тиск та інші життєво важливі показники.

Неофіційні лексичні одиниці, що пов'язані $з$ описом працівників лікарні та пацієнтів, утворені переважно на основі метафор і метонімії. Так, група професійних категорій медичних працівників та їх характеристики яскраво представлена такими прикладами: baby catcher (ловець немовлят) - акушер;

blood suckers (п'явки, кровососи) / vampires (вампіри) - медичні працівники, які беруть кров на аналіз;

Dr. Feelgood (Лікар Почуваєте-себе-добре) лікар, який призначає лікування, не задумуючись;

knife-happy (радий помахати ножем) - опис надто “активного” хірурга.

Широко розповсюдженою $\epsilon$ група нестандартних слів і виразів, часто грубих і зневажливих, які описують хворих або їх стан:

banana (банан) - хворий з жовтяницею;

boyfriend (кавалер) - літній дідусь, про якого приємно піклуватися;

whale (кит) - пацієнт з надлишковою вагою; yellow submarine (жовта субмарина) огрядний хворий $з$ жовтяницею.

Сленгізми, що означають різні медичні маніпуляції та процедури, утворюються головним чином за допомогою скорочень:

bronk - "bronchoscope" - робити бронхоскопію;

cath - "catheter" - катетеризувати;

bag - "oxygen bag" - давати кисневу подушку; scope - "endoscope" - робити ендоскопію.

В групі сленгових одиниць, що пов’язані 3 видами, підрозділами та характеристиками медичних установ, так само як і при визначенні

Match the slang units with their definitions. Explain your choice

Task 1.

\begin{tabular}{|l|l|}
\hline 1. Ash cash & a) Intesive care or mortuary \\
\hline 2. Wall & b) Oxford Handbook for Clinical Medicine \\
\hline 3. Eternal care & c) By pretending it's not there, one hopes it will go away \\
\hline $\begin{array}{l}\text { 4.Ostrich } \\
\text { treatment }\end{array}$ & d) Money paid for signing cremation forms \\
\hline 5. Bible & e) A physician who resists admitting patients at all costs \\
\hline 6.Frequent flyer & f) A physician who admits almost every patients he sees \\
\hline 7. Sieve & $\begin{array}{l}\text { g) A regular patient in the hospital who often sees medical attention for every little health } \\
\text { problem encountered }\end{array}$ \\
\hline 8.September club & h) Not-so-exclusive group of students doing retakes \\
\hline
\end{tabular}

Task 2.

Match the slang units with their definitions. Analyze the parts of the slang units

\begin{tabular}{|c|c|}
\hline 1. Acopia & a) An expensive procedure \\
\hline 2. Adminisphere & b) Removing parents as an effective cure to child's problems \\
\hline 3. Fascinoma & c) Nuclear medicine \\
\hline 4. Scepticemia & d) An interesting medical rarity \\
\hline $\begin{array}{l}\text { 5.Unclear } \\
\text { medicine }\end{array}$ & $\begin{array}{l}\text { e) A nurse who has just came back from an intensive training and acts like a doctor on the } \\
\text { floor }\end{array}$ \\
\hline 6. Walletectomy & f) Inability to cope. Used as a diagnosis predominantly in the elderly. \\
\hline 7. Noctor & g) What physicians develop with experience \\
\hline 8. Parentectomy & h) Refers to the parts of the hospital where the managers work \\
\hline
\end{tabular}




\section{ОСОБЛИВОСТІ АНГЛЙСЬКОГО МЕДИЧНОГО СЛЕНГУ ТАОЗНАЙОМЛЕННЯ З НИМ СТУДЕНТІВ ВИЩИХ МЕДИЧНИХ НАВЧАЛЬНИХЗАКЛАДІВ ЯК ЗАСІБ МОТИВУВАННЯ ДО ВИВЧЕННЯ IНОЗЕМНОЇМОВИ}

медичного персоналу i хворих, широко представлені скорочення, метафора і метонімія:

adminisphere (адмінісфера) - частини лікарні, в яких працює адміністрація;

metabolic clinic (метаболічна клініка) кімната для відпочинку персоналу;

rheumaholiday (ревмовідпустка) - ревматологія (вважається відділенням, де робота менш інтенсивна);

departure lounge (зала очікування) геріатрична палата.

Вищенаведені приклади сленгових утворень та лексичний матеріал для завдань нижче запозичені iз наукових досліджень $[2 ; 4 ; 11]$, публікацій в періодичних виданнях $[3 ; 5 ; 7 ; 12]$ та словників англійського медичного сленгу [1;9].

Запропоновані нами приклади завдань побудовані на встановленні відповідностей між сленговими одиницями та їх визначеннями. Нестандартні слова і вирази утворені на основі метафоризації та метонімії (Завдання 1) і словоскладання із словотворчих елементів англійської мови та греко-латинських терміноелементів, що також набули переносного значення (завдання 2).

Виконання завдань на ознайомлення із сленговими утвореннями сприяє оволодінню студентами словами і виразами професійного мовлення, що останнім часом використовуються в неофіційному спілкуванні медичними працівниками в англомовних країнах, та створенню невимушеної обстановки і позитивному налаштуванню під час заняття.

Висновки. Незважаючи на сумніви щодо етичності використання деяких нестандартних слів і виразів з галузі медицини, беззаперечним залишається сам факт існування даного феномену та його динамічне поширення в сучасному мовленні. Сленг швидко розвивається і посуває стандарти традиційної мови.

Ознайомлення студентів вищих медичних навчальних закладів із яскравими зразками англійських професійних сленгових одиниць і засобами їх утворення поповнює їх словниковий запас для спілкування у ненормативному медичному дискурсі і сприяє посиленню мотивації до вивчення іноземної мови.

\section{ЛІТЕРАТУРА}

1. Decoding 28 Medical Slang Terms. [Електроннии pecypc]. - Режим доступу: https:// health.howstuffworks.com/medicine/healthcare/ decoding-28-medical-slang-terms.htm

2. Fox A. T. Medical Slang in British Hospitals. [Електроннии ресурс]. - Режим доступу: https:// pdfs.semanticscholar.org/383 f/ 582b3ec755c48077d54b58b87ce85d3d8801.pdf

3. Gillis M. Medical jargon may cloud doctor-patient communication. [Електроннии ресурс]. - Режим доступу: https://www.reuters.com/article/us-healthjargon-patient-communication/medical-jargon-may-clouddoctor-patient-communication-idUSKBN1EQ17B

4. Gyuro M. Teaching Medical Slang and Jargon. [Електроннии ресурс]. - Режим доступу: https://unibge.hu/Root/Sites/BGF/Kutatasi-tevekenyseg/ Folyoiratok kiadvanyok/Prosperitas-folyoirat/Tartalom/ 2017/2017-IV/dokumentumok/41_49_oldal.pdf

5. Houseton M. Medical Matters: The Rude Lexicon of Medical Slang, from Acronyms to Argot... [Електроннии pecypc]. - Режим доступу: https://www.irishtimes.com/ life-and-style/health-family/medical-matters-the-rudelexicon-of-medical-slang-from-acronyms-to-argot1.2161160

6. Keeley P. Pimp my slang. [Електроннии ресурс]. Режим доступу: https://www.bmj.com/content/335/7633/ $\underline{1295}$

7. Lost in Translation: the Impact of Medical Jargon on Patient-Centred Care. [Електроннии ресурс]. - Режим доступу: https://www.theguardian.com/healthcarenetwork/2014/jul/01/impact-medical-jargon-patientcentred-care

8. McDonald P. S. Slang in Clinical Practice. [Електроннии ресурс]. - Режим доступу: https:// www.ncbi.nlm.nih.gov/pubmed/12193372

9. Medical Slang Glossary. [Електроннии ресурс]. Режим доступу: http://www.translationdirectory.com/ glossaries/glossary224.php

10. Parsons G. N. Between Two Worlds. Medical Student Perception of Humor and Slang in the Hospital Setting. [Електроннии ресурс]. - Режим доступу: https:/ /www.ncbi.nlm.nih.gov/pubmed/11556931

11. Stojanova I. Informal Medical Discourse: Notes on Specialized Slang, Jargon and Proverbs. [Електроннии pecypc]. - Режим доступу: https://ibn.idsi.md/sites/ default/files/imag file/Informal $\% 20$ medical $\%$ 20discourse $\% \begin{array}{lllllllllllllllllll}\% & 2 & 0 & \% & 2 & 0 & \% & 2 & 0 & \mathrm{n} & \mathrm{o} & \mathrm{t} & \mathrm{e} & \mathrm{s} & \% & 2 & 0 & \mathrm{o} & \mathrm{n}\end{array} \%$ 20specialized $\% 20$ slang $\% 20 \% 2 \mathrm{C} \% 20$ jargon $\% 20$ and $\% 20$ proverbs.pdf

12. The Secret Slang of Hospitals: What Doctors and Nurses Call Patients behind Their Backs. [Електроннии pecypc]. - Режим доступу: https://nationalpost.com/ health/the-secret-slang-of-hospitals-what-doctorsnurses-call-patients-behind-their-backs

\section{REFERNCES}

1. Decoding 28 Medical Slang Terms. [Electronic resource]. Available at: https:/health.howstuffworks.com/ medicine/healthcare/decoding-28-medical-slangterms.htm[in English].

2. Fox, A. T. Medical Slang in British Hospitals. [Electronic resource]. Available at: https:// pdfs.semantics cholar.org/383f/ 582b3ec755c48077d54b58b87ce85d3d8801.pdf[in English].

3. Gillis, M. Medical jargon may cloud doctor-patient communication. [Electronic resource]. Available at: https:/ /www.reuters.com/article/us-health-jargon-patient- 


\section{ЗАГАЛЬНОНАУКОВІ ПДХОДИ ДОСЛДЖЖЕННЯПРОФЕСІЙНОӦ ПІГОТОВКИ МАЙБУТНІХ ФАХІВЦІВ-МІЖНАРОДНИКІВ У СИСТЕМІ ВИЩОЇ ОСВІТИ УКРАЇНИ}

communication/medical-jargon-may-cloud-doctor-patientcommunication-idUSKBN1EQ17B[in English].

4. Gyuro, M. Teaching Medical Slang and Jargon. [Electronic resource]. Available at: https://uni-bge.hu/ Root/Sites/BGF/Kutatasi-tevekenyseg/ Folyoiratok kiadvanyok/Prosperitas-folyoirat/Tartalom/ 2017/2017-IV/dokumentumok/41 49 oldal.pdffin English].

5. Houseton, M. Medical Matters: The Rude Lexicon of Medical Slang, from Acronyms to Argot... [Electronic resource]. Available at: https://www.irishtimes.com/lifeand-style/health-family/medical-matters-the-rude-lexiconof-medical-slang-from-acronyms-to-argot-1.2161160[in English].

6. Keeley, P. Pimp my slang. [Electronic resource]. Available at: https://www.bmj.com/content/335/7633/1295 [in English].

7. Lost in Translation: the Impact of Medical Jargon on Patient-Centred Care. [Electronic resource]. Available at: https://www.theguardian.com/healthcare-network/ 2014/jul/01/impact-medical-jargon-patient-centred-care [in English].
8. McDonald, P. S. Slang in Clinical Practice. [Electronic resource]. Available at: https://www.ncbi.nlm.nih.gov/ pubmed/12193372 [in English].

9. Medical Slang Glossary. [Electronic resource] Available at: http://www.translationdirectory.com/ glossaries/glossary224.php [in English]

10. Parsons, G. N. Between Two Worlds. Medical Student Perception of Humor and Slang in the Hospital Setting. [Electronic resource]. Available at: https:// www.ncbi.nlm.nih.gov/pubmed/11556931 [in English].

11. Stojanova, I. Informal Medical Discourse:Noteson Specialized Slang, Jargon and Proverbs. [Electronic resource]. - Available at: https://ibn.idsi.md/sites/default/files/imag file/Informal $\% 20$ medical\%20disc ourse $\% 20 \% 20 \% 20$ notes $\% 20$ on $\% 20$ speci alized $\% 20$ slang $\% 20 \% 2 \mathrm{C} \% 20$ jargon $\% 20 \mathrm{and} \% 20$ proverbs.pdf [in English].

12. The Secret Slang of Hospitals: What Doctors and Nurses Call Patients behind Their Backs. [Electronic resource]. Available at: https://nationalpost.com/health/ the-secret-slang-of-hospitals-what-doctors-nurses-callpatients-behind-their-backs [in English]

Стаття надійшла до редакції 21.07.2018

УДК 94:327.378.14

DOI:

Марія Клепар, кандидат педагогічних наук, доиент кафедри міжнародних відносин

Прикарпатського національного університету імені Василя Стефаника

\section{ЗАГАЛЬНОНАУКОВІПІХОДИ ДОСЛДЖЕННЯ ПРОФЕСІЙНОЇПІДГООВКИ МАЙБУТНІХ ФАХІВЦІВ-МІЖНАРОДНИКІВ У СИСТЕМІ ВИЩОЇ ОСВІТИ УКРАЇНИ}

У статті здійснено синтезований аналіз загальнонаукових підходів дослідження професійної підготовки студентів-міжнародників у закладах вищяої освіти України. З'ясовано суть, змістовнофункціональне наповнення і операційно-дослідницький потенціал системного, структурно-функціонального, інтегративного, парадигмального, антропологічного, аксіологічного, феноменологічного методологічних підходів у контексті досліджуваної проблеми.

Ключові слова: підхід; методологічний підхід; професійна освіта, педагогічна наука, підготовка майбутніх фахівців-міжнародників.

תim. 11.

Mariya Klepar, Ph. D.(Pedagogy), Associate Professor of the International Relations Department Precarpathian Vasyl Stefanyk National University

\section{GENERALAPPROACHES OFTHE STUDY OF PROFESSIONAL PREPARATION FOR FUTURE FACULTY-INTERVIEWS IN THE HIGHER EDUCATION SYSTEM OF UKRAINE}

In the article a synthesized analysis of the general scientific approaches of the study of professional training of specialists in international relations in institutions of higher education of Ukraine is carried out. The essence, content-functional filling and operational-research potential of the system, structural-functional, integrative, paradigm, anthropological, axiological, acmeological, phenomenological methodological approaches in the context of the problem under study are found out.

It is shown that the concept "approach" is one of the most commonly used in pedagogical studies. As synonymous with the concepts "pedagogical approach", "scientific approach", "methodological approach", which are often identified with the concepts "principle", "method", etc., are used. Proceeding from the objective tendency of expanding the semantic space of the categorical apparatus of modern pedagogical science, it is proved that the concept "scientific approach", "methodological approach", "research approach" in general are identical and can be used: a) to designate a strategic line defining the basic theoretical the position and directions of the research process; b) as a methodological regulation of constructing a scientific search and determining the main parameters 